\title{
Between fragments and fullness: Worshipping in the in- between spaces of Africa
}

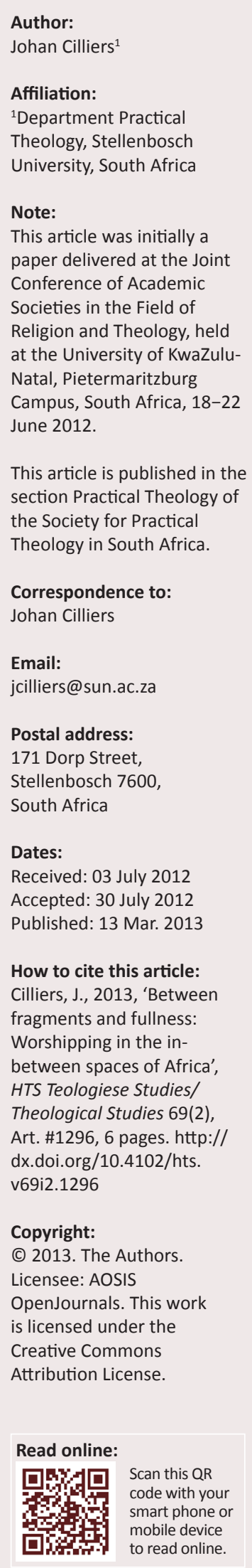

In this article the aesthetical practical theological notion of fragment, as introduced by the German Practical Theologian Henning Luther, was brought into dialogue with the African understanding of fullness, as articulated for instance in the concept Ubunye [we are one]. In the light of this, some basic tensions of worshipping in Africa were profiled, id est the dynamic interaction between individuality and communality, between the already and the not yet (present and future), between identity as being and identity as becoming, et cetera. The article concluded with some suggestions concerning worship in Africa as a space of paradox.

\section{Introduction}

\section{Liturgy as in-between space of tension}

Worship is an in-between experience (cf. Cilliers 2009b:167-179). It takes place within the dynamic spheres of several tensions, with the (eschatological) tension between the 'already' and the 'not yet' forming the overarching leitmotiv. Put in other terms, it could also be called:

an experience of liminality, which implies an ambiguous phase between two situations or statuses. Often this in-between space or liminal experience is filled with potential and creativity, but also with risk and danger. (Cilliers 2009a:25)

Liturgy can indeed be lethal - for normative discourse and conventional theory. ${ }^{2}$ But it is, in my opinion, exactly in this high-voltage space of tension that the sparks of true worship fly. Of course many tensions could be mentioned here, for instance between being and becoming; between time and space; between awe and expression; between laughter and lament; between praising God and edifying believers; between individuality and communality; between engaging the mind, but also the emotions, and the will of human beings, et cetera (cf. Tubs-Tisdale 2001:175-188; also Cilliers 2009a:21-26). It is important to note, however, that they are indeed tensions which should not be resolved, as they give a profile to, and express the existential dynamics that describe the concept: life. If liturgy (leitourgia) is also meant to be liturgy of life (latreia - liturgy on the street), then existentialia like these should surely be brought into view and into liturgical consideration ${ }^{3}$ (see Cilliers 2009a:21-26). In this article I restrict myself to two tensions that have been closely linked to the question of identity, namely the experience of fragment and the experience of fullness. These categories of fragment and fullness could be understood on different levels, for instance as aesthetical, existential, emotional, psychological and social phenomena. What follows is an effort to place these two keywords within a theological and specifically eschatological-liturgical framework.

\section{Identity: The experience of fragment}

During the late 1980s the German practical theologian Henning Luther introduced the notion of fragment, which has its origins in aesthetics, into the theological debate. ${ }^{4}$ He turned to the concept of fragment to challenge a specific understanding of identity that professes to deliver and maintain a product that is completely intact and fully integrated (Luther 1992:160). Luther opted rather to speak about identity as not-being-whole, not-being-complete, and constantly-being-interrupted, that is, as fragment (Luther 1992:161). This understanding of identity as fragment stands in stark contrast to one of totality, of a state of closed-in-itself wholeness, of unfailing unity, and of continuous and unchallenged relevance (Luther 1992:180-182).

\footnotetext{
1.It breathes 'a sense of displacement, that sense of being in no man's land, where the landscape appears completely different, there is no discernible road map, and where the journeyer is jolted out of normalcy' (Franks \& Meteyard (2007:216). Franks and Meyetard here use the geographical metaphor of a 'no man's land'. Obviously, eschatological liminality entails more than geography (space) and even temporality (time). It rather indicates a new reality (novum) within the existing reality.

2.Characteristically the liminal phase is constituted by the convergence or interweaving of qualities of both categories between which it is sandwiched: 'Since the liminal is neither fully one type of space (category) nor the other, it will take on aspects of both; it is this indeterminacy of quality and therefore unpredictability that creates the aspect of danger' (Kunin 1989:30; see Cilliers 2009a:25).

3.The amplified Bible translates Roman 12:1 as follows: 'I apply to you therefore, brethren, and beg of you in view of all the mercies of God, to make a decisive dedication of your bodies - presenting all your members and faculties - as a living sacrifice, holy (devoted, consecrated) to God, which is your reasonable (rational, intelligent) service and spiritual worship.' Reasonable service and spiritual worship (Iatreia) are closely related to leitourgia, and encompasses the whole of life. Cf. Hess (1978:549-551).
}

4.This discussion is taken as excerpt from Charles Campbell and Johan Cilliers (2012:45-48). 
According to Luther, there are fragments from the past as well as fragments from the future (Luther 1992:167). The fragments from the past are those pieces of unfinished business that were never resolved, those shards of a once-intact but now-destroyed whole, haunting us as torsos, as ruins, reminding us, amongst other things, of our guilt. These fragments from the past can create experiences of pain and anguish that lead to mourning and lament. Luther even speaks of 'aesthetics of confession'.

The fragments of the future, on the other hand, signify unfinished business that has to do with those experiences and endeavours of life that have not yet found their ultimate form and completion. These fragments of the future evoke feelings of longing in us (Luther 1992:169) - feelings that prevent us from dull acceptance, or worse, hardening or solidifying (Luther 1992:170). These longings help us to remain open and fluid toward the future.

These fragments from the past and the future point to something other than and outside of themselves, to possibilities that yet need to be fulfilled (Luther 1992:167). The unique contribution of Henning Luther lies in the fact that he interpreted the aesthetic notion of fragment in an innovative, theological way. As a matter of fact, Luther is convinced that the notion of fragment runs like a golden thread throughout all the classic theological topoi. It, for instance, gives profile to the key concept of faith, preventing identity from becoming an immovable monument, instead fostering a specific understanding of faith: faith means not to be intact, but rather to live as a fragment.

Fragmentation also fosters a specific understanding of love. Love involves grasping that we are not the only fragments on this earth, and that our conceptions of identity are continuously challenged by others; we are bound to one another and should create space for each other, in love (Luther 1992:170). Those who understand something of their own brokenness cannot be without love for others who are also broken. They know from existential experience that fragments can and should coexist in love; they must not be allowed to develop rigid boundaries or exclusive clubs. As a matter of fact, sin can be understood as a form of identity that seeks security in set and final statuses, directly the opposite of being a fragment (Luther 1992:172).

Perhaps the notion of fragment is best underlined by the key word grace, which implies an understanding that we are not yet whole, but continuously being made whole by Another (Luther 1992:173). We are indeed fragments, but not looselying bits and pieces; we are continuously being fitted into a larger picture of fulfilment.

For Luther, the cross of Christ represents fragmentation par excellence. Jesus was not, in this sense, an ideal and 'whole' human being. He was broken, pierced, crucified, and fragmented. This fragmentation is furthermore not annulled by the resurrection; the resurrection is not the negation of the cross, but its validation (Luther 1992:173). The resurrection

5.See Luther (1992:182) - A striking example of this fragment from the past can be seen in the Church of Remembrance [Gedächtniskirche] in Berlin: a church bombed during the Second World War that was not renovated, but left as a ruin to act as a monument of remembrance for the generations to come. Next to it a modern a monument of remembrance for the generations to come. Next to it a modern
church has been built -intended as a contrast, adding to the architectural tension of fragment and completion, placed within a few meters of one another. says, ' $[t]$ his broken and fragmented Christ is none other than God.' The resurrection in fact deepens and radicalises the reality of the cross. But it also gives hope that the fragments of our existence are being bound together in a new whole. ${ }^{6}$ It is important to understand, however, that there is no logical connection between crucifixion and resurrection. The leap from crucifixion to resurrection is strange, surprising, and puzzling, not something dictated by logic. It is not something we would 'normally' perceive, or simply hear and take to heart. The Spirit must give us discernment.

From an eschatological perspective, the fragments are real, but not meant to be eternal incompleteness; they are rather indicators and forerunners of the consummation of fullness (Luther 1992:175). This understanding of the fragmentation of life gives hope, but can also create feelings of unrest, of knowing that we have not yet arrived at our destinations. In fragments, lament and longing are bound together; in fragments, fullness as not-being-there is present as beingthere. Fragmentation thus characterises Christian life in the liminal space between the ages.

Luther's theological understanding of identity and fragment represents brokenness, but as such calls for, longs for, wholeness - and so create hope. ${ }^{7}$ These and other liminal tensions should, however, not be understood in an individualistic way, but rather within community, which brings us to our next dimension of identity.

\section{Identity: The experience of fullness}

African spirituality ${ }^{8}$ is expressed, inter alia, in the concept of Ubunye, which literally means: we are one. ${ }^{9}$ This has got to do

6.Manfred Josuttis (1998:117-118, 126) would add to this insight by saying: when the Spirit of Christ lives in us and we become part of the history of Christ, our fragmented identity participates in the consummation of the resurrected Christ Josuttis in fact speaks about conversion rather than identity, because 'conversion' intends transformation, whilst 'identity' has conservation in mind - therefore, rather conversion than conservation.

7.This seems to resonate with Martin Luther's understanding of a theologia crucis. In his Heidelberg disputations (section 21), Luther states that, whilst a theology of glory speaks well of the bad and calls the bad good, it is the theology of the
cross that describes essential reality and perceives being in terms of its essential cross that describes essential reality and perceives being in terms of its essential
characteristics (matter as it is). Martin Luther [1518] 1883:354: 'Theologus gloriae characteristics (matter as it is). Martin Luther [1518] 1883:354: 'Theologus gloriae
dicit malum bonum et bonum malum, Theologus crucis dicit id quod res est.' In dicit malum bonum et bonum malum, Theologus crucis dicit id quod res est.' In section 20, Luther states that the visible, as well as the not-yet-revealed (or future)
aspects of the presence of God should be perceived from the perspective of aspects of the presence of God should be perceived from the perspective of
suffering (the cross). In this sense, the cross becomes a resource of comprehension and understanding - and therefore hope in the midst of suffering. Martin Luther [1518] 1883:354: 'Sed qui visibilia et posteriora Dei per passiones et crucem conspect intelligit.' For Luther, the most authentic locus of our human knowledge of God is the cross of Christ in which God is revealed and yet, paradoxically, also hidden away. God is revealed in the passiones et crucem - yet God is simultaneously hidden in this revelation.

8.It is not that easy to try and define African spirituality as such. As a matter of fact, it is near impossible. It is impossible to do justice to the richness of this concept within the limitations of this article. Actually one cannot speak of African culture and spirituality in the singular. Africa is a vast continent, incorporating a wide variety of cultures and ethnic term 'Africa' dhe concept of spirituality is of course also complex. For the sake of this contribution I understand spirituality to be the 'spirit' (life force; energy, essence) of a specific culture, expressing the mos basic values of that culture: 'Spirituality means that which influences a person to live in a mode that is truly fulfilling' (Skhakhane 1995:106). Of course there is also no homogeny in terms of the understanding of 'Divinity' in Africa. It is impossible to go into detail concerning all the nuances you find on our continent in this regard. For a good overview, cf. Smith (1966; see Cilliers 2008a).

9.One could of course also mention concepts like Ubuntu and Amandla as part and parcel of African spirituality. As a matter of fact, these concepts could be seen as intrinsically intertwined. Ubunye (the unity of all reality) is kept intact through Amandla [power], which in turn operates within Ubuntu [community] Cilliers (2008a). These concepts can however not be described in detail within the limitations of this article. For an overview, cf. Ramose (1999:49f.); Setiloane (1989:34); Shutte (1993:46); Kriel (1989). One must furthermore also not forget that the African paradigm in which Ubunye operates is often also hierarchical and patriarchal and that the notion of Ubunye could not prevent many incidents of patriarchal and that the notion of Ubunye could not prevent many incidents of
ethnic conflict and even cleansing on our continent. Ubunye should therefore not ethnic conflict and even cleansing 
with the integration of life, which also includes the spirit world and the departed ancestors. In Africa, life is not divided into compartments, with separate 'spiritual' and 'secular' components. Life as such is spiritual. Life is perceived not as fragments, but rather as a wholesome, holistic experience (Cilliers 2008a; cf. Skhakhane 1995:106).

Without romanticising the issue, it could be said that Africans, indeed, have a more systemic understanding of life. Life is a dynamic space for holistic relationships, an integral whole of cosmic and social events. Africans adopt a non-analytical approach to our existence on this planet, epitomised in the words of Berinyuu (1988):

In Africa, there is no division and/or differentiation between the animate and inanimate, between the spirit and matter, between living and non-living, dead and living, physical and metaphysical, secular and sacred, the body and the spirit, etc. Most Africans generally believe that everything (human beings included) is in constant relationship with one another and with the invisible world, and that people are in a state of complete dependence upon those invisible powers and beings. Hence, Africans are convinced that in the activities of life, harmony, balance or tranquillity must constantly be sought and maintained. Society is not segmented into, for example, medicine, sociology, law, politics and religion. Life is a liturgy of celebration for the victories and/or sacrifices of others. (p. 5; see Cilliers 2008a)

This differs quite considerably from a Western approach to life. Whilst analyses, solutions and consumerism are typical of the latter, myth and symbol, ritual and rhythm determine everyday life in the African context (Cilliers 2008a).

The way people relate to the environment and the nature of inter-personal relationships are all part of the spiritual makeup of the African. Issues of moral behavioural patterns; natural plagues and disasters; familial inter-connectedness; domestic animals; fields (the land ethic) and several rites directly linked to particular events in the life of the individual and the community, together belong to the African religiocultural substratum. Social and economic relations, especially in the traditional society, continue incessantly to pervade the spiritual realm of the African. Mtetwa (1996) formulates this spirit of Ubunye as follows:

The conclusion we arrive at with regard to what does and what does not belong to African Spirituality is the fact that there exists a very thin line of demarcation between the religious and the cultural phenomena in African cosmology. Religion and culture are inextricably intertwined. Most of the religious rituals are appropriated into the cultural scheme of things and the cultural domain shapes and influences the religious philosophy and practices. It is in this context and against that background that any attempt to dichotomize African Spirituality into the sacred and the secular; the physical and the spiritual; the individual and the corporate, results in gross distortion and mis-construal of its theology and its praxis. ${ }^{10}$ (p. 23; see Cilliers 2008a)

10.This sense of unity with(in) the universe has been imbedded in African spirituality since the dawn of time. It is depicted on many of the rock paintings that can be found throughout Southern Africa. In an example found at Lonyana Rock in KwaZulu-Natal the community is dancing around a sick person lying under a karos (animal skin). But the living animals are also there - the food stock. They seem to be moving in and out of the circle. Here, in one artwork, we find community, childcare (women accompanying children), religion (expressed in the dance), medicine, work (hunting), etc. in an intertwined spirit of holism. This is indeed an apt depiction of African spirituality (Cilliers 2008a).

\section{Worshipping in the tension between fragments and fullness}

As point of departure, we have already noted that worship takes place within certain spheres of tension - reflecting the realities of life. As fragments and fullness form part and parcel of these tensions, I am of the opinion that they should indeed be reflected in liturgy. If the tension between these two existentialia is broken or ignored or avoided, it can in fact have detrimental effects on liturgy, indeed on life. The idea of fragment (perhaps found more within Western understandings of identity) could for instance deteriorate into social separation - as happened during the time of apartheid in South Africa. Seen from the South African context the idea of fragmentation could never again be romanticised. It would indeed seem that fragment, if not understood in a theologically responsible way, could either be misunderstood as a romanticised ideal or rejected as a form of extreme relativity.

A fragment can in fact become an enclave, within which a community hopes to find a safe haven against the 'enemy' outside the enclave (cf. Cilliers \& Nell 2011). Fragment then becomes ontologised as an eternal state of affairs - in fact the exact opposite to what Henning Luther proposed. But the idea of fragment could also lead to a strong individualistic tendency, with strong consumerist overtones. It could prompt a habitus that says: I am alone, and I need to fulfil all my needs. The fragment then becomes an island, a perceived and guarded paradise of content.

A pertinent question to ask here would be whether the spirit of Ubunye has in fact been affected by this habitus of consumerism. The latter seems to have been accelerated after the demise of apartheid and the exposure of the country to the international world, and therefore the technological mass media and the impact of globalisation - which was artificially kept away from the population by the apartheid government. It would seem as if especially Americanism has exerted its grip on the African spirituality of the integration of life, threatening to shatter and indeed fragment it.

Americanism could perhaps be described as the ideological movement from democracy to democratism; from moralethical stances to the prescriptive morals of achievement ethics; from systemic concepts to the networking of megacompanies and imperialistic economic strategies. The essence of Americanism could in fact probably be best summarised in terms of its keyword: consumerism. Behind this keyword lurk a number of intertwined ideological paradigms, for instance the frenzied search for so-called 'quality'. Materialism here takes on the form of a pathological competition to own the right 'brand' and 'label'. The sole object is to surpass normal consumption and to reach the highest peaks of luxury: always bigger and better. Mass production follows and creates the latest trends in order to rake in the profits. For this, of course, you need an effective advertising machine, supplied by the technological mass media (Cilliers 2008a). 
Globalisation then takes on the form of a materialistic imperialism, a market driven economical manipulation that networks in such a manner that a new 'McWorld' is created, a world within which particular cultures are denied their regional and national features. This brand of globalisation has been characterised as the 'cultural assault' of McDonalds, Coca-Cola, Disney, Nike, MTV, et cetera (Cilliers 2008a; cf. Zwingle 1999:12-13; also Louw 2002:340).

One of the hinges on which Americanism turns, is the privatised and individualised democratisation of all spheres of life. The American dream breathes the expectancy of a 'good life', the fulfilment of all needs and in the end, the satisfaction of the self. Human rights become 'my rights', the freedom to do and to possess and to experience within the paradigm of a me, I, and myself-generation. The whole notion of unity and community is reduced and trivialised in favour of the individual - the fragment - in the grip of global consumerism (Cilliers 2008a). ${ }^{11}$

Indeed, the spirit of Ubunye can be threatened by a reductionist understanding of 'fragment'. But in my opinion it also needs the tension that is given in the relationship to fragment. 'Fullness' can also become deaf and blind to the challenge and necessity for transformation; can become so complete and rounded off, that it is no longer open to meaningful change. It can in fact solidify into a state of totality, of closed-in-itself wholeness, of unfailing unity, and of continuous and unchallenged relevance - precisely the understanding of identity that Henning Luther opposed. Or, to put it in theological terms: it can become so fixated, that it no longer moves forward in (eschatological) time. 'Already' then triumphs over 'not yet'.

The concept of eschatology however hinges on God's acts in history, God's presence now, but also God's coming in the future. ${ }^{12}$ The integration of life may therefore never become a closed system, but is always provisional and preliminary - open towards the future and therefore continual transformation. These elements do not seem to function that explicitly in Ubunye. Some African scholars point out that Africa's understanding of time is cyclical, with past events returning eternally in the memories of communities. Time could therefore consist of the present, the experienced past and a very short future (Cilliers 2008a; cf. Bosman 2001:105).

The inherent tension between fragment and fullness calls for a new appraisal of some basic tensions of worshipping in

11.This form of Americanisation seems to influence every nook and cranny of the globe, flattens every cultural crease, and indeed produces one big 'McWorld'. Hollywood, which represents the glitzy side of Americanism, seems to be hovering everywhere. For instance, on mural paintings, to be found throughout South Africa (especially in the townships) that keeps on popping up amidst the African figures and typical African settings? To name but a few: Conan the Barbarian, The Incredible Hulk, The Simpson Family (which both epitomise and caricatures the American way of life), the Ewing family (from the television series Dallas), and apparently an all-time favourite: Mickey Mouse! (Cilliers 2008a).

12. Obviously the future by implication means 'not now' - the future is the future - but this is often misunderstood as an experience of time exclusively related to a futurum, that is, an attitude or mentality that somehow bypasses the present in its eagerness for the future. In the New Testament sense of the word, advent indicates a close connection between the saving presence of Christ who has already come and the future. The hour that is coming, already is now (cf. Jn $4: 23$; already come and the future. The hour that is coming, already is now (cf. Jn 4:23;
$5: 25)$. The Christian hope is more about adventus (the coming of the present One), than it is about futurum. Cf. Moltmann (1969:177-178).
Africa, id est the dynamic interaction between individuality and communality, between the already and the not yet (present and future), between identity as being and identity as becoming, et cetera. All of these tensions in turn prompt us to reconsider worship as a space of paradox.

\section{Conclusion Worship as a space of paradox}

At its heart, liturgy hinges on paradox; it is in fact liturgy's intrinsic intention to create and sustain paradoxes by holding together 'unconventional and destabilizing pairings of opposites' (Brown 1995:30). ${ }^{13}$ This in turn presupposes a God-image in which God is present in this world and is revealed sub contrario [in contradictions]. God is present in God's world only as a stranger, as a suffering servant, as the Crucified One - thus the shocking paradox of God's revelation to us. God is present contrary to (para) the appearance (doxa) of the opposite (Berkhof 1979:54). In fact, paradox could be described as holding together irreconcilable opposites in order to create and sustain the tension of liminality.

Paradoxical utterances are no strangers to the vocabulary of faith (cf. Brueggemann's (1997:317-403). ${ }^{14}$ They are found throughout scripture, where the ultimate paradox of God's story is intrinsically intertwined with our story (Cilliers (2008c:62-76). It is not incidental that the paradoxical twists that shift our minds, the juxtapositions that invite us to reconsider, the strange counter-testimonies that have an iconoclastic and anti-ideological function, are found throughout the biblical texts. ${ }^{15}$ Again and again we encounter these destabilising pairs of opposites - expressing the 'infinite tension' at the heart of the gospel (Tillich 1948:165) - which employ conventional language unconventionally to interrupt our set 'structures' of faith and indeed our fixated concepts of worship. These 'pairs of opposites' seem to hold together two, often disparate, realities at the same time, disrupting static order and calling for discernment. It is in fact characteristic of paradox: it not only arrests attention, but stimulates 'further questions, speculation, qualification, even contradiction' on the part of the audience. Paradox creates and sustains liminal spaces at the very 'limits of discourse' (see Colie 1969:92-97).

13.Although Brown here focuses on Paul's rhetoric, the notion of paradox could also be viewed as an intrinsic part of liturgical rhetoric.

14.It is also not by coincidence that the concept of fragment has its roots in aesthetics. It has in fact become a type of keyword for modern aesthetics. Therefore it is understandable that people like Bertolt Brecht and others like him have defined their work as preliminary, as 'fragmentary work for an unfinished world'. Brecht wrote within the dialectic of intended completion and inescapable world'. Brecht wrote within the dialectic of intended completion and inescapable
partiality, of continuity and deterioration, and speaks about the tension between partiality, of continuity and deterioration, and speaks about the tension between
'Ruinenästhetik' and 'dem technologischen Fortschrittsbegriff' that characterised 'Ruinenästhetik' and 'dem technologischen Fortschrittsbegriff' that characterised
his life's work. But he did not try and escape this tension - rather embraced it. Cf. Fetscher (2010:580). The same could be said about Pablo Picasso. His work could perhaps be described as a combination of 'two principles of representation, the "figurative" and the "dissociative". Figurative painting is based on the laws of perspective and use of nature as a model. Dissociative painting, by contrast, frees itself from the single-perspective viewpoint: the front and the back are seen simultaneously in the same picture, objects and individual parts of the body seen simultaneously in the same picture, objects and individual parts of the body appear as if dispersed - dissociated - and there is no longer any outline to indicate the "natural" shape of an object.' In this sense, 'fullness' is never understood without 'fragment'. The liminal character of Picasso's 'style' could be described as: the movement between figuration and dissociation, that is, between figure and fragment. See Buchholz and Zimmerman (1999:66); also Campbell and Cilliers
(2012:14).

15.In Brueggemann's discussion of counter-testimony. 
Liturgy, being a form of aesthetics, represents a distinct space of paradox. ${ }^{16}$ It connects to life exactly because it condenses this paradoxical tension and movement between fragments and fullness. It does this through imaginative symbols and paradoxical speech, perhaps even best through silence which goes against the grain of every form of consumerism (cf. Cilliers (2008b:19-35). And it is within this space of paradox, that the revelation of God contrary to (para) the appearance (doxa) of the opposite can be experienced.

We tend to shy away from paradox. Paradox can be painful and disturbing; can create uneasiness. Therefore we often try to overcome paradox, to find solutions, to relieve tensions. But we in fact need paradox, simply because it corresponds with the ambiguities of life. And it is within the spaces of liturgy that life is experienced in a condensed manner, and life can be celebrated, but also lamented in hope - because the fragments of our existence are continuously - through grace - being fitted into a bigger picture of fullness.

Worship that does not understand the realities of our fragmented existence (and therefore lament) can also not truly understand what the celebration of our hope for fullness entails. Without lament, celebration is distorted into becoming artificial rituals, or cosmetic frivolity, or, at its worst, consumer-orientated entertainment (cf. Cilliers 2012:152-161).

Without the dimension of lament, worship indeed becomes a 'safe haven' in the sense that it simply serves and maintains the processes of domesticated civilisation. Yet worship opens up a paradoxical space in which we are taken out of our zones of comfort and confronted by realities that matter. In lament human beings are revealed in all their finiteness and frailty - as fragments - and never idealised or spiritualised. Lament corrects a false or naïve view of faith. It does not represent a failure of faith, but an act of faith. It knows no cheap answers and quick fixes. It does not cover up the rawness of reality, but describes it 'as it is' (Ackermann 2001:16). Lament exposes theological and liturgical kitsch. It does not romanticise God's involvement in our lives; does not settle for a God 'who is covered with a sugar-coated veneer of religious optimism whose omnipotence will "make everything right in the end"' (Ackermann 2001:27-28). God is not sanitised and removed from the ugliness of suffering. On the contrary, God is viewed as intimately involved in our suffering.

We indeed need to re-learn the language of lament, which can only be understood within the eschatological tension between 'already' (fullness) and 'not yet' (fragment). This tension is in turn only understood within the theological framework of hope. Christian hope does not necessarily alleviate the realities of present conflict and suffering, or does not necessarily make them more palatable, on the contrary, it could intensify these experiences (Moltmann 1971:146). When the community of faith knows that the future (the fullness of the pleroma in Christ) is present, it receives new language (modes of 16.Cf. the exposition by Cilliers (2012:69f.). expression) and new inspiration to protest against the conflict and suffering of the present. Liturgy always carries within it this inescapable paradox: it celebrates the reality of being, also of a new being, but at the same time, and exactly because of the reality of this new being, it laments the fact that there are still other realties that hamper us in becoming what we could be. We could indeed say: 'Christian worship is inherently eschatological - calling us to hope in God's present and coming reign, even as we name the realities that distort and oppose that reign in our world' (Tisdale 2001:182).

The two-pronged liturgical question in this regard would be: do our worship services create spaces where we indeed celebrate the presence, id est the adventus of the future (also being part of its fullness); but do they also create spaces where we can lament over experiences of contingency and fragmentation, refusing to gloss over the conflict and suffering in this world (thus acknowledging that we are still in a process of becoming)? Or have our 'praise and worship' become shallow and our lament cheap? The latter seems to be the inevitable consequence when the eschatological tension between 'already' and 'not yet' is sidestepped or softened.

When the paradoxical tension between celebration and lament is lost or solved, celebration ironically also becomes just another consumerist activity in a market-driven society in which weakness and failure, and therefore lament, can have no place. Lament - if it is still present - in turn becomes institutionalised, mechanical and meaningless. One could say: lament loses its eschatological edge, loses its tension and urgency. It has become complacent and domesticated, satisfied with being without becoming, with clichés not born out of awe, and being fixed in space indeterminately. It no longer understands a theology of sighing, and therefore has no inkling of a theology of singing.

\section{Acknowledgements Competing interests}

The author declares that he has no financial or personal relationship(s) that may have inappropriately influenced him in writing this article.

\section{References}

Ackermann, D., 2001, Tamar's cry: Re-reading an ancient text in the midst of an HIV/ AIDS pandemic, Ecumenical Foundation of Southern Africa (EFSA), Stellenbosch.

Berinyuu, A.A., 1988, Pastoral care to the sick in Africa, Peter Lang, Frankfurt am Main. Berkhof, H., 1979, Christian faith, Eerdmans, Grand Rapids.

Bosman, H., 2001, 'All past and present but little future? African and Old Testament concepts of time and history', in M. Getui, K. Holter \& V. Zinkuratire (eds.), Interpreting the Old Testament in Africa, pp. 103-112, Peter Lang, New York.

Brown, A.R., 1995, The cross and human transformation: Paul's Apocalyptic word in 1 Corinthians, Fortress, Minneapolis.

Brueggemann, W., 1997, Theology of the Old Testament: Testimony, dispute, advocacy, Fortress, Minneapolis.

Buchholz, E.L. \& Zimmerman, B., 1999, Pablo Picasso: Life and work, Könemann Cologne.

Campbell, C.L. \& Cilliers J.H., 2012, Preaching fools: The Gospel as a rhetoric of folly, Baylor University Press, Waco, TX.

Cilliers, J.H., 2008a, 'Formations and movements of Christian Spirituality in urban African contexts', paper presented at the conference Interkulturelle Religionshermeneutik - Das Verstehen des Fremden, Religion und Politik in Afrika, Humboldt University, Berlin, 10 July. 
Cilliers, J.H., 2008b, 'Silence is Golden: Liturgy Beyond the Edge of Language', Praktiese Teologie in Suid-Afrika 23(1), 19-35.

Cilliers, J.H., 2008c, 'Skrifbeskouing en Skrifhantering: Perspektiewe op ' Hermeneutiek van Verwagting', Verbum et Ecclesia 29(1), 62-76. http://dx.doi. org/10.4102/ve.v29i1.5

Cilliers, J.H., 2009a, 'Why Worship? Revisiting a Fundamental Liturgical Question', HTS Teologiese Studies/Theological Studies 65(1), 21-26. http://dx.doi.org/10.4102/ hts.v65i1.126

Cilliers, J.H., 2009b, 'Worshipping in the "in-between" times of transition: Reflections on the liminality of liturgy', in H. Pieterse \& C Thesnaar (eds.), A Faithful Witness: Essays in Honour of Malan Nel, pp. 167-179, Bybel Media, Wellington.

Cilliers, J.H., 2012, Dancing with deity: Re-imagining the beauty of worship, BybelMedia, Wellington.

Cilliers, J.H. \& Nell, I.A., 2011, 'Within the enclave: Profiling South African social and religious developments', paper presented at the International and interdisciplinary religious developments', paper presented at the International and interdisciplinary conference of The impact of global religious transformations on social cohesion
and social development in different cultural contexts, Berlin, 25-28 November.

Colie, R.L., 1969, 'Problems of paradoxes', in K. Williams (ed.), Twentieth century interpretations of the praise of folly, pp. 92-97, Englewood Cliffs, New York.

Fetscher, J., 2010, 'Fragment', in K. Barck, M. Fontius, D. Schlenstedt, B. Steinwachs \& F. Wolfzettel (Hrsg.), Ästhetische Grundbegriffe, Studienausgabe, Band 2, pp. 551-588, J.B. Metzler, Stuttgart/Weimar.

Franks, A. \& Meteyard, J., 2007, 'Liminality: The Transforming Grace of In-Between Places', The Journal of Pastoral Care and Counseling 61(3), 215-222.

Hess, K., 1978, 'Latreuō', in C. Brown (ed.), Dictionary of New Testament Theology, vol. 3, pp. 549-551, Paternoster, Exeter.

Josuttis, M., 1998, 'Identität und Konversion', in D. Stollberg (Hrsg.), Identität im Wandel in Kirche und Gesellschaft, pp. 118-127, F.S. Richard Riess, Göttingen.

Kriel, A., 1989, Roots of African thought: Sources of power - A pilot study, University of South Africa, Pretoria.
Kunin, S.D., 1989, God's place in the world: Sacred space and sacred place in Judaism, Cassell, London \& New York. PMCid:1026931

Louw, D.J., 2002, 'Pastoral Hermeneutics and the Challenge of a Global Economy: Care to the Living Human Web', The Journal of Pastoral Care and Counseling 56(4), 337-348.

Luther, H., 1992, Religion und Alltag: Bausteine zu einer Praktischen Theologie des Subjekts, Radius, Stuttgart.

Luther, M., [1518] 1883, 'Disputatio Heidelbergae habita', in Die Weimarer Ausgabe (WA), pp. 350-374, Hermann Böhlau, Weimar.

Moltmann, J., 1969, Geloof in de toekomst, Amboboeken, Utrecht.

Moltmann, J., 1971, Die ersten Freigelassenen der Schöpfung: Versuche über die Freude an der Freiheit und das Wohlgefallen am Spiel, Kaiser Verlag, München.

Mtetwa, S., 1996, 'African Spirituality in the Context of Modernity', Bulletin for Contextual Theology in Southern Africa and Africa 3(2), 23-31.

Ramose, M.B., 1999, African philosophy through ubuntu, Mond Books, Harare.

Setiloane, G.M., 1989, African theology: An introduction, Skotaville Publishers, Johannesburg

Shutte, A., 1993, Philosophy for Africa, UCT Press, Rondebosch.

Skhakhane, J., 1995, 'African spirituality', in M. Makobane, B. Sithole \& M. Shiya (eds.), The church and African culture, pp. 105-115, Lumko, Germiston.

Smith, E.W., 1966, African ideas of God, Edinburgh House Press, London.

Tillich, P., 1948, 'Born in the grave', in The Shaking of the Foundations, pp. 164-168, Scribner, New York.

Tisdale, L.T., 2001, 'Navigating the contemporary worship narrows: Channel markers for deep waters', in B.K. Blount \& L.T. Tisdale (eds.) Making Room at the Table: An Invitation to Multicultural Worship, pp. 175-188, Westminster John Knox Press, Invitation
Louisville.

Zwingle, E., 1999, 'Goods Move. People Move. Ideas Move. And Cultures Change', National Geographic 196(2), 12-19. 